口腔領域悪性腫瘍の臨床病理学的検討

第 7 報 舌癌 Stage I, II 症例の頸部リンパ節後発転移について

\author{
富島修・山城正宏・砂川元・金城 孝 \\ 新崎章
}

\title{
Clinico-pathological study on maxillo-oral malignant tumor
}

\section{Cervical metastasis after treatment without local recurrence in stage I and II of tongue cancer}

\author{
Osamu Tomishima - Masahiro Yamashiro - Hajime Sunakawa \\ Takashi KInJo $\cdot$ Akira ARASAKI
}

\begin{abstract}
Characteristics of cervical metastasis after treatment without local recurrence in Stage I and II of tongue cancer were investigated from clinico-pathological findings.

Metastasis after treatment was found in 5 out of 23 cases. The incidence of lymphnode metastasis by therapeutic modality indicated that cervical metastasis occurred in one case $(8.3 \%)$ treated by surgery, and in 4 cases $(36.4 \%)$ of those treated with radiotherapy. In these 4 cases, the total dose of radiation to the primay lesion ranged from 8,500 rads to $15,959 \mathrm{rad}$, and averaged $11,840 \mathrm{rad}$. Duration from the time of starting the treatment to that of palpation of cervical metastasis was 4-7 months.

Location of metastasis nodes were level I and II in the level of involvement proposed by the UICC. Clinically, the metastatic rate was $33.3 \%$ in $\mathrm{T} 1,14.7 \%$ in $\mathrm{T} 2,22.2 \%$ in exophytic growth type, and $20.0 \%$ in endophytic growth type. Histologically, these cases were classified into three of grade $2(4 / 8,50.0 \%)$ and one of grade $4 \mathrm{D}(1 / 1,100 \%)$ in the mode of invasion. On the differentiation of the tumor, metastasis was found in 2 cases (18.2\%) of well differentiated, in 2 cases $(22.2 \%)$ of moderately differentiated and in one case (33.3 $\%$ ) of poorly differentiated.

C.P. the 4 cases in which metastasis occurred were low grade malignancies. This suggested that metastasis that occured after treatment was related to the therapeutic method.
\end{abstract}

Key words: tongue cancer, cervical metastasis after treatment, clinical-pathological study

緒

言

口腔癌の頸部リンパ節転移は，患者の予後を左右する 重要な因子である．舌癌においても頸部リンパ節転移の 様相と各種治療法拈よび各種臨床病理学的所見, 予後と

琉球大学医学部菌科口腔外科学講座

（主任：山城正宏教授）

Department of Oral Surgery, School of Medicine, University of the Ryukyus (Chief: Prof. Masahiro Yamashiro)
の関連について検討した報告が多くみられる1 19). 從 来, 舌癌の治療は, 放射線療法, 外科療法が主体であ り, 各種治療法の進歩と相まって, その治療成績は徐々 に向上しつつある。しかし, 初診時, Stage I, II の非 進行例で, 治療後, 原発巣のコントロールがなされてい るにもかかわらず，頸部リンパ節後発転移により，しば しば不幸な転帰をとる症例も少なくない，今回，われわ れは, 局所再発例を除く, 舌癌一次症例の中, Stage I, II の後発転移について臨床病理学的検討を行ったので 報告する。 


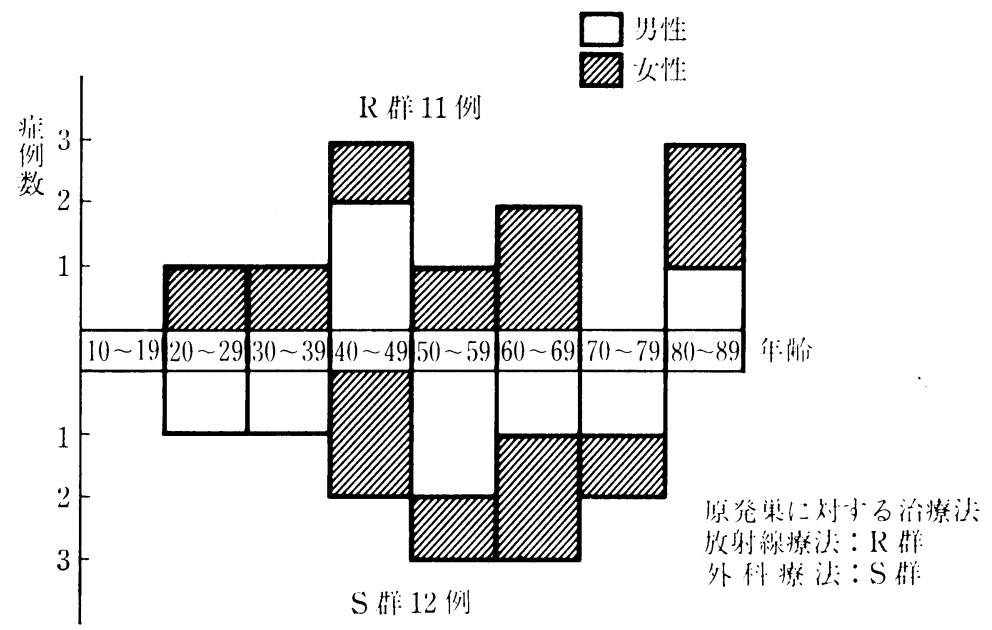

図 1 舌癌 Stage I, II 症例の性, 年龄別, 治燎法別頻度

\section{対象および方法}

1973年 9 月より1986年 8 月までの過去13年間に当科を 受診した舌癌一次症例は 72 例でそのうち初診時, Stage I , II 症例は39例であった.この Stage I, II 症例中, 局所再発例 2 例を除き, 後述の各種臨床病理学的所見を 満足する23症例を対象とした。性別, 年踚別構成は, 男 性 9 例, 女性14例で, 年齡は25歳から89歳にわたり, 平 均 55.7 歳であった. Stage 別内訳では, Stage I が 8 例, Stage II が15例であった。治療法別では，原発巣に 対して放射線治療を行ったR群が11例，手術を行った $\mathrm{S}$ 群が12例であった（図1）.

今回，この 23 症例に扣いて沿療法別の後発転移の有無 牤よび, 後発転移 (十) 群と後発転移 (一) 群の各種臨 朱病理学的所見の比較検討を行った。臨床所見として は, UICC の TNM 分類 ${ }^{20)} に よ る T$ 分類および腫瘍の 発育様式について，また病理組織学的所見としては，初 診時の $\mathrm{HE}$ 生検標本から, 組織学的分化度, 癌細胞浸 潤様式（山本，小浜の分類 1981) ${ }^{21)}$ ，腫場間質に打ける 単核細胞浸潤度, 細胞異型度 (CAT), 構造異型度 (SAT) について, 後発転移との関連性の検討を行った.

\section{結果}

\section{1. 治療法別後発転移の頻度}

原発巣に対する治療法別内訳は，外科療法12例，放射

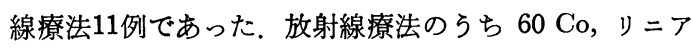
ック, ベータトロンなどの外部照射を行った症例は 6 例 で, Ra 針, Ir 針, Au grain による組織内照射が 5 例 に行われていた。放射線療法群11例の照射線量は 4,000
表 1 治燎法別後発転移凖

\begin{tabular}{c|c|c|c}
\hline & $\mathrm{R}$ & $\mathrm{S}$ & 計 \\
\hline \begin{tabular}{c|c} 
後発転移 \\
$(+)$
\end{tabular} & $\begin{array}{c}4 \\
(36.4 \%)\end{array}$ & $\begin{array}{c}1 \\
(8.3 \%)\end{array}$ & $\begin{array}{c}5 \\
(21.7 \%)\end{array}$ \\
\hline $\begin{array}{c}\text { 後発転移 } \\
(-)\end{array}$ & $\begin{array}{c}7 \\
(63.6 \%)\end{array}$ & $\begin{array}{c}11 \\
(91.7 \%)\end{array}$ & $\begin{array}{c}18 \\
(78.3 \%)\end{array}$ \\
\hline & 11 & 12 & 23 \\
\hline
\end{tabular}

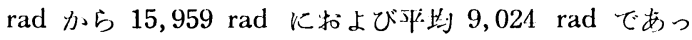
た。外科潦法を行った 12 例中1 例 $(8.3 \%)$, 放射線療法 を行った 11 例中 4 例 $(36.4 \%)$ ，に後発転移を諗めた

\section{(表1).}

後発転移を垫めた 5 症例の臨水病理学的所見は, ' $\mathrm{I}$ 分 類では, T $1: 3$ 例, T 2: 2 例, 発青様式では, 外问性 発育型：4 例, 内问性発育型：1例, 分化度では, 高分 化型： 2 例, 中等度分化型 : 2 例, 低分化型 : 1 例, 癌 細胞浸潤様式では, 2 型：4 例, $4 \mathrm{D}$ 型：1 例, 単核細 胞浸潤度では強：1例, 中：2 例, 弱：1例, CAT, SAT では，II，2型：4 例，III， 3 型：1例であった （表 2).

転移を認めた 4 例の照射線量は 8,500 rad から15,959 $\mathrm{rad}$ に拈よび，その平均照射線量は，11,840 rad であ った.この 4 例中 2 例に外部照射, 他の 2 例に組織内照 射が行われていた，外科療法群，放射線療法群のいずれ においても Bleomycin や FT 207 による補助的化学療 法が行われていた．治療開始より転移が明らかになるま での期間は， 4 か月から 7 か月にわたり，平均 4.7 か月 であった。 リンパ節転移部位について， UICC の level of involvement (1978) に従って検索したところ, level 
表 2 後発転移を認めた 4 症例の臨床病理学的所見

\begin{tabular}{|c|c|c|c|c|c|c|c|c|c|c|c|}
\hline 症例 & 姓 & 年齢, & & $\begin{array}{l}\text { 腫痬の } \\
\text { 大きさ }\end{array}$ & $\mathrm{T}$ 分類 & 発育様式 & 分化度 & 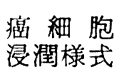 & $\begin{array}{l}\text { 単核細胞 } \\
\text { 浸潤 度 }\end{array}$ & CAT & SAT \\
\hline 1 & & 47歳 & $\hat{\sigma}$ & $30 \times 25 \mathrm{~mm}$ & 2 & 外向性 & 高 & 2 型 & 中 & II & 2 \\
\hline 2 & & 55 歳 & 우 & $10 \times 9 \mathrm{~mm}$ & 1 & 内向性 & 低 & 4 D型 & 中 & $\mathbb{I I}$ & 3 \\
\hline 3 & & 66歳 & 우 & $25 \times 18 \mathrm{~mm}$ & 2 & 外向性 & 中 & 2 型 & 強 & II & 2 \\
\hline 4 & & 30歳 & 우 & $13 \times 19 \mathrm{~mm}$ & 1 & 外向性 & 高 & 2 型 & 㐷 & II & 2 \\
\hline 5 & & 46歳 & 우 & $12 \times 12 \mathrm{~mm}$ & 1 & 外向性 & 中 & 2 型 & 中 & II & 2 \\
\hline
\end{tabular}

表 3 後発転移を認めた 4 症例の原発巣の治㙩法，転移部位，転移までの 期間，および予後

\begin{tabular}{|c|c|c|c|c|}
\hline 将:例 & 原华望!二对与る活燎法 & $\begin{array}{c}\text { 䡮移部位 } \\
\text { (UICCの分措) }\end{array}$ & 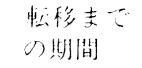 & 手; 後 \\
\hline 1 & $\begin{array}{l}\text { Ir 組綀内照射 } \\
\qquad 15,959 \mathrm{rad}\end{array}$ & & 約 4 か力 & $\begin{array}{l}\text { Ao (5年 } \\
3 \text { 少) }\end{array}$ \\
\hline 2 & $\begin{array}{ll}\text { Co } & 2,400 \mathrm{rad} \\
\text { リニア・ク } & 6,000 \mathrm{rad}\end{array}$ & & 約 7 か月 & $\begin{array}{l}\mathrm{Dc}(1 \text { 年: } \\
10 \text { か力 }\end{array}$ \\
\hline 3 & Co $\quad 14,500 \mathrm{rad}$ & & 約 4 加月 & $\begin{array}{l}\operatorname{Dc}(2 \text { 年 } \\
11 \text { 名 })\end{array}$ \\
\hline 4 & $\begin{array}{r}\text { Au grain 祖峨内照射 } \\
8,500 \mathrm{rad}\end{array}$ & $\mathrm{F}^{-}$ & 的 4 加月 & $\begin{array}{l}\mathrm{Ao}(9 \text { 年 } \\
11 \text { 名 }\end{array}$ \\
\hline 5 & 古部分切除術 & $y^{\infty}$ & 胱4.5 力 月 & $\begin{array}{l}\mathrm{Ao}(4 \text { 年 } \\
11 \text { 力 月 }\end{array}$ \\
\hline
\end{tabular}

I にのみ転移を諗めた症例は 5 例中 1 例, level II にの みが 2 例，他の 2 例は level I，IIに及んでいた。また 4 例中 3 例は患側にのみで, 他の 2 例は, 左右の level I と対側の level II にリンパ節転移を誋めた。このよう にリンパ節転移は level I， II を中心に認められ，後発 転移を認めた 5 症例の予後は 3 例が Ao で， 2 例が Dc であった（表了）。

\section{2. 臨床所見と後発転移との関連}

$\mathrm{T}$ 分類では, 対象 23 症例中 $\mathrm{T} 1$ 症例は 9 例, $\mathrm{T} 2$ 症 例は14例であり，後発転移を認めたのは T 1 症例では 9 例中 R 群が 2 例 $(22.2 \%), \mathrm{S}$ 群が 1 例 $(11.1 \%), \mathrm{T} 2$ 症例では14例中 $\mathrm{R}$ 群が 2 例 $(14.3 \%)$ であった。発育様 式関しては, 外向性発育型が18例で内向性発育型が 5 例であり, Stage I, II の非進行例では外向性発育型症 例が多かった，発育様式と後発転移との関連では，外向 性発育型の 18 例中 $\mathrm{R}$ 群の 3 例 $(16.7 \%), \mathrm{S}$ 群の 1 例
$(5.6 \%)$ K, 内向性発育型では 5 例中 R 群の 1 例 $(20.0$ \%) に後発転移を認めた（表 4).

\section{3. 病理組織学的所見亡後発転移との関連}

分化度別には, 高分化型が 11 例と最も多く, 中等度分 化型が 9 例, 低分化型が 3 例であり, 低分化型症例は少 なかった。分化度別後発転移の発現頻度は, 高分化型11 例中 R 群の 2 例 $(18.2 \%)$ ，中等度分化型 9 例中 R 群の 1 例 $(11.1 \%), \mathrm{S}$ 群の 1 例 $(11.1 \%)$, 低分化型 3 例中 $\mathrm{R}$ 群の 1 例 (33.3\%) であった。

腫癔宿主間の境界部に扰ける癌細胞浸潤様式は， 2 型 が 8 例と最も多く, 1 型 7 例, 3 型 5 例, $4 \mathrm{C}$ 型 2 例, $4 \mathrm{D}$ 型 1 例であり， 1 型， 2 型か $65.2 \%(15 / 23)$ と多 数を占めていた。癌細胞浸潤様式と後発転移との関連で は, 1 型拉よび 3 型, $4 \mathrm{C}$ 型では全例後発転移を認め ず, 2 型 8 例中 R 群の 3 例 $(37.5 \%), \mathrm{S}$ 群の 1 例 $(12.5$ $\%), 4 \mathrm{D}$ 型の 1 例 $(100 \%)$ に後発転移か認められた。 
表 4 臨床所見と後発転移との関連

\begin{tabular}{|c|c|c|c|c|c|c|}
\hline & & \multicolumn{2}{|c|}{ 後発転移（一） } & \multicolumn{2}{|c|}{ 後発転移 $(+)$} & \multirow{2}{*}{ 計 } \\
\hline & & $\mathrm{R}$ & $\mathrm{S}$ & $\mathrm{R}$ & $\mathrm{S}$ & \\
\hline \multirow{2}{*}{$\mathrm{T}$ 分 類 } & 1 & 0 & $6(66.7 \%)$ & $2(22.2 \%)$ & $1(11.1 \%)$ & 9 \\
\hline & 2 & $7(50.0 \%)$ & $5(35.7 \%)$ & $2(14.3 \%)$ & 0 & 14 \\
\hline \multirow{2}{*}{ 発育様式 } & 外向性 & $5(27.8 \%)$ & $9(50.0 \%)$ & $3(16.7 \%)$ & $1(5.6 \%)$ & 18 \\
\hline & 内向性 & $2(40.0 \%)$ & $2(40.0 \%)$ & $1(20.0 \%)$ & 0 & 5 \\
\hline
\end{tabular}

表 5 病理組織所見と後発転移との䦌速

\begin{tabular}{|c|c|c|c|c|c|c|}
\hline & & \multicolumn{2}{|c|}{ 後発転移（一） } & \multicolumn{2}{|c|}{ 後発転移（+） } & \multirow{2}{*}{ 計 } \\
\hline & & $\mathrm{R}$ & $\mathrm{S}$ & $\mathrm{R}$ & $\mathrm{S}$ & \\
\hline \multirow{3}{*}{ 分 化 度 } & 高 & $4(36.4 \%)$ & $5(45.4 \%)$ & $2(18.2 \%)$ & 0 & 11 \\
\hline & 中 & $2(22.2 \%)$ & $5(55.6 \%)$ & $1(11.1 \%)$ & $1(11.1 \%)$ & 9 \\
\hline & 低 & $1(33.3 \%)$ & $1(33.3 \%)$ & $1(33.3 \%)$ & 0 & 3 \\
\hline \multirow{5}{*}{$\begin{array}{l}\text { 瘦 細 胞 } \\
\text { 浸潤様式 }\end{array}$} & 1 & $1(14.3 \%)$ & $6(85.7 \%)$ & 0 & 0 & 7 \\
\hline & 2 & $3(37.5 \%)$ & $1(12.5 \%)$ & $3(37.5 \%)$ & $1(12.5 \%)$ & 8 \\
\hline & 3 & $2(40.0 \%)$ & $3(60.0 \%)$ & 0 & 0 & 5 \\
\hline & $4 \mathrm{C}$ & $1(50.0 \%)$ & $1(50.0 \%)$ & 0 & 0 & 2 \\
\hline & $4 \mathrm{D}$ & 0 & 0 & $1(100 \%)$ & 0 & 1 \\
\hline \multirow{3}{*}{$\begin{array}{l}\text { 単核細胞 } \\
\text { 浸潤 芰 }\end{array}$} & 強 & $3(37.5 \%)$ & $4(50.0 \%)$ & $1(12.5 \%)$ & 0 & 8 \\
\hline & 中 & $4(28.6 \%)$ & $7(50.0 \%)$ & $2(14.3 \%)$ & $1(7.1 \%)$ & 14 \\
\hline & 弱 & 0 & 0 & $1(100 \%)$ & 0 & 1 \\
\hline \multirow{3}{*}{$\mathrm{CAT}$} & $\mathrm{I}$ & 0 & $4(100 \%)$ & 0 & 0 & 4 \\
\hline & II & $6(37.5 \%)$ & $6(37.5 \%)$ & $3(18.8 \%)$ & $1(6.3 \%)$ & 16 \\
\hline & III & $1(33.3 \%)$ & $1(33.3 \%)$ & $1(33.3 \%)$ & 0 & 3 \\
\hline \multirow{3}{*}{$\mathrm{SAT}$} & 1 & 0 & $4(1.00 \%)$ & 0 & 0 & 4 \\
\hline & 2 & $6(37.5 \%)$ & $6(37.5 \%)$ & $3(18.8 \%)$ & $1(6.3 \%)$ & 16 \\
\hline & 3 & $1(33.3 \%)$ & $1(33.3 \%)$ & $1(33.3 \%)$ & 0 & 3 \\
\hline
\end{tabular}

単核細胞浸潤度別には，中症例が14例と最も多く，強 症例は 8 例, 弱症例は 1 例と少なかった。単核細胞浸潤 度と後発転移との関連をみると, 強症例では 8 例中 R 群 の 1 例 $(12.5 \%)$, 中症例は 14 例中 R 群の 2 例 (14.3 $\%), \mathrm{S}$ 群の 1 例 $(7.1 \%)$, 弱症例では 1 例中 R 群の 1 例 $(100.0 \%)$ 飞後発転移を認めており，浸潤の程度に 応じた結果を示していた。
細胞異型度 (CAT), 粠造異型度 (SAT) は, ともに I , 1 型が 4 例, CAT, SAT ともにII, 2 型が16例,

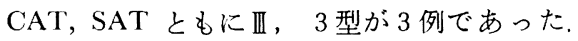

$\mathrm{CAT}, \mathrm{SAT}$ と後発転移との関連では CAT I, SAT 1 の症例に後発転移を認めなかったが, CAT II , SAT 2 では 16 例中R 群の 3 例 $(37.5 \%), \mathrm{S}$ 群の 1 例 $(6.3 \%), \mathrm{CAT} \mathbb{I I}, \mathrm{SAT} 3$ の症例では 3 例中 R 群 
の1例 $(33.3 \%)$ に後発転移を認めた（表 5 ).

\section{考察}

口腔癌の頸部リンパ節転移は, 患者の予後を左右する 重要な因子の一つであり, 口腔癌のなかでも舌癌では, 頸部リンパ節転移の発現率が他の部位に比べ高いとされ ている ${ }^{8,11,17)}$. 従来, 舌癌の治療法では, 放射線療法, 外科療法が主体であるが，各種治療法の進歩と相まっ て，その治療成續は，徐々に向上しつつある。しかし， 初診時, Stagc I, II の非進行例で, 治療後, 原発巣の コントロールがなされているにもかかわらず, 頸部リン 八節後発転移により，しばしば不幸な転帰をとる症例も 少なからず経験される。

今回, われわれは, 舌癌一次症例中, Stage I, II の 後発転移飞関する臨床病理学的検討を行ったのでその結 果について考察した。

臨床所見の $\mathrm{T}$ 分類と頸部リンバ節後発転移との関連を みると, T 1 では 9 例中 3 例 $(33.3 \%)$ に, T 2 では14 例中 2 例 $(14.3 \%)$ に後発転移を認め, T 1 の頻度がや や高かった，発育様式と頸部リンパ節後発転移につい て,これまでの報告のほとんどが, 外向性発㕕型に比 べ, 内向性発育型に後発転移が多いとしている ${ }^{6,18)}$ 自 験例においては, 外向性発育型 18 例中 4 例 (22.3\%), 内向性発育型 5 例中 1 例 $(20.0 \%)$ に後発転移をきたし て拐り, 外向性発育型がやや高いが大差はなかった。

病理組織学的所見のらち癌細胞浸潤様式と後発転移と の関連について, 今回, 山本, 小浜の分類 (1981) を用 いて検索したところ，腫瘍宿主間の境界線が明嘹である 1 型は 7 例みられたが, 後発転移をきたした症例はな く，諸家の報告に打いても，後発転移率が低かった6) この 7 症例の治療は 1 例が放射線療法で，他の 6 例はす べて外科療法が行われていた，乙かし今回検索した症例 中, 2 型は 8 例で，その5ち 4 例に後発転移をきたして おり，2 型においても戦重な予後観察の重要性が示㖫さ れた。ちなみにこの 2 型 4 例中 3 例は放射線療法， 1 例 は外科社法が施行されて扣り, またその澏細胞浸潤様式 以外の各種所見は, $\mathrm{T}$ 分類では $\mathrm{T} 2: 2$ 例, $\mathrm{T} 1: 2$ 例 で, 発育様式では, 4 例すべて外向性発育型で, 臨林所 見においては明らかな関連性を認めなかった。また転移 をきたした 2 型 4 例の病理組織学的所見について, 分化 度では高分化型 2 例, 中等度分化型 2 例で, 単核細胞浸 潤度では，強，弱がそれぞれ 1 例，中が 2 例， CAT，

SAT に执いては 4 症例ともすべて CAT II, SAT 2 で あり，とくに癌細胞浸潤椂式以外の所見で悪性度が高い といら傾向はなかった。

転移をきたした残りの $4 \mathrm{D}$ 型の 1 例には放射線療法 が行われていた。

原発巣に対し外科療法で切除後, 後発転移をきたした
場合，術前に micro metastasis がすでに存在している 場合と，術中の癌紐胞播種の場合がある ${ }^{3,20,21)}$ 。放射線 療法を行った場合は, 放射線の種頪, 照射方法, 照射 量, 照射期間, 針刺入時の機珹的刺激, 癌細胞そのもの の変化, さらに前述の臨床病理学的各種所見との関連, また特に放射線照射に上る宿主免疫能の变化など, 後発 転移との間に種々複雑な関連の可能性が示㖫され, 今後 さらに症例を積み重ね検討することが必要であると思わ れる。1984年, 山本らは, 原発宩切除後, 局所再発なく 後発転移をきたした非進展舌癌症例の検討を行い3)，16 例中 5 例飞後発転移を認めており, その 5 症例の癌細胞 浸潤様式はすべて 4 型（4 C 型 3 例， $4 \mathrm{D}$ 型 2 例）で, 1 型， 2 型， 3 型には転移を認めておらず，原発栄切除 群においての後発転移は癌細胞浸潤様式とかなり一致し ているとして, $4 \mathrm{C}$ 型, $4 \mathrm{D}$ 型症例においての予防的郭 清術の必要性を強調している。 しかし前述のごとく, 自 験例においては, 放射線療法を行った 2 型の 3 例, 外科 療法の 1 例飞後発転移を認めており, 放射線療法症例に おいては初診時生検による癌細胞浸潤様式と後発転移と の関連は明確ではなかった。今回検索した 23 例中, 後発 転移を認めた 5 例中 4 例は放射線療法群で，また前述の ごとく癌細胞浸潤様式が $4 \mathrm{D}$ 型の 1 例を除いた 3 例で は, 臨床病理学的覀性度はそれ㕶高くなく治療法との 関連性が示唆された。照射方法別後発転移率は，外照射 群が 3 例中 2 例 $(66.7 \%)$, 組織内照射群が 3 例中 2 例 (66.7\%) であり雨者間に差は認められなかった。リン 節転移は外科療法群に比べ放射線療法群に多いといら 報告は立花，奥田らによってもなされており，放射線療 法でも組織内照射症例に転移が多く8,9), 針刺入時の機 械的刺激が転移を促している可能性があるとしている. また天笠らは4), 舌癌の一次治療後の頸部リンバ節転移 の発現頻度について, 推計学的な差は認めていないが, Stage I, II 合わせて外科療法群では $18.2 \%$, 放射線療 法群では $34.6 \%$ とし放射線療法群に比べ外科療法群に打 いて頸部転移の出現頻度が低かったと報告している。 た荫本らは5), 初診時 $\mathrm{N} 0$ であった舌癌 57 例中 18 例に 後発転移があったとし，このうち組織内照射群が31例中 15例 (48.4\%) に, 切除主体群が21例中 3 例 (14.3\%) に後発転移を認めている。ささらに組織内照射群でもとく に $4 \mathrm{C}, 4 \mathrm{D}$ 型に, 切除主体群では 3 型症例に頻度が高 かったと報告している，放射線療法群の 2 型 3 例すべて に後発転移を認めたわれわれの結果とは若干異なってい た。

近年, 放射線照射と宿主免疫能の関連についての報告 も散見されており ${ }^{22 \sim 25)}$, 放射線治療中, 治療後の宿主免 疫能の变化々後発転移との関連性も今後検討の必要があ ると思われる。外科療法, 化学療法においても同様なこ とがいえる26,27)

舌癌ハムスターに扣いてコーチゾン投与群と非投与群 
での、リンパ節転移は前者のほうが多いという報告があ り ${ }^{28)}$ ，またラットに打いて局所放射線照射に扰ける照射 線量と所属リンパ節転移との関係で $30 \mathrm{~Gy}$ 群と $60 \mathrm{~Gy}$ 群では，後者のほうに多く認められたとする報告もあ る22) これらは転移形成と宿主免疫能および放射線照射 との関連性を示唆している，初診時生検標本上での腫瑝 間質に抢ける単核細胞浸潤度と後発転移との関連では, その程度に応じて後発転移の発現頻度が高くなってい る。平塚らは ${ }^{299}$ ，原発部の $\mathrm{T}$ 細胞浸潤程度とリンパ節転 移の有無との間に推計学的な有意差を認めておりりリンン パ球サブセットの解析も今後重要な課題であろう.

頸部リンパ節後発転移をきたすまでの期間は，4 か月 から 7 か月に及び平均 4.7 か月で，すべて 1 年以内に後 発転移をきたして扣り，放射線療法を行った舌癌症例に おける諸家の報告とほぼ同栐な結果であった。自験例に 扣いて外科療法群の後発転移は 1 例のみであったが, 平 塚らは ${ }^{30)}$, 舌癌Stage I, II 症例に扣ける原発巣切除後 に後発転移をきたした 7 症例について検討を行ってい る. そのなかで後発転移をきたした期間は 6 か月から 2 年 6 か月, 平均 1 年 3 か月で, そのうち 5 症例は 1 年以 以に転移が認められて扣り, 外科療法群と放射線療法群 の後発転移をきたすまでの期間にはあまり差がなかっ た。この結果からみると micro metastasis の存在は無 視できないが，平侬らが述べているよらに免疫療法が後 発転移を途延せしめている可能性もあり, 後療法の有無 など， micro metastasis をいかに制御していくかは，今 後の検討課題であろう，今回娭索した症例について免疫 学的検索は行っておらず, それについて言及することは できなかったが，治療法と宿主免疫能拈よび後発転移の 関係を各種臨术病理学的所見をふま克, 症例を重ねて梌 討していくことが重要であると考える。

\section{結語}

舌癌 Stage I, II 症例 23 拝例の頸部リンバ節後発転 移について臨床病理学的検討を行い次の結果を得た。

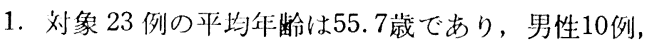
女性13例であった。

2. 放射線療法を行った 11 例中 4 例 $(36.4 \%)$, 外科療 法群 12 例中 1 例 $(8.3 \%)$ に後発転移を認めた。

3. 後発転移を認めた 4 症例の平均照射線量は 11,840 $\mathrm{rad}$ で，治療開始より転移を認めるまでの期間は 4 か月 から 7 か月にわたり，平均 4.7 か月であった。外部照射， 組織内照射間に後発転移率の差はなかった。

4. 後発転移リンパ節領域は, Level I, II に集中し ていた。

5. 患者の予後は，後発転移を認めた 5 例中， 3 例か Ao で， 2 例かＤc であった。

6. T $1, T 2$ 間および外向性発育型, 内向性発育型間
に拈ける後発転移率に大差はなかった。

7. 分化度別後発転移率は，高分化型 $(18.2 \%)$ ，中等 度分化型 $(11.1 \%)$ ，低分化型 $(33.3 \%)$ で低分化型か： やや高い結果であった。

8. 癌細胞浸潤様式では, 2 型（8例中 4 例, $50.0 \%$ ), $4 \mathrm{D}$ 型（1例中 1 例 $100 \%$ ） 飞後発転移を認め, 1 型, 3 型, $4 \mathrm{C}$ 型では認められなかった。

9. 腫澺間質に扣ける単核細胞浸潤度に括いては，強， 中, 弱に従って, 順次高い後発転移率を示した。

稿を終えるにあたり，こ協力いただいた本院放射線 科，ならびに他の諸先生に対し，謝意を表します。

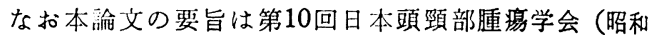
61 年 6 月，仙台）にて報告した。

\section{引 用 文 献}

1）木下靬彦, 本間義郎, 他 : 舌癌症例の臨床病理 学的検討一钼部リンパ節転移について一. 日ロ 外誌 31：1715-1721 1985.

2) 藤谷哲造, 服部 浩, 他：舌痹の顽部転移に関 寸る臨床的検討。耳舅臨床 70：939-946 1977.

3）宮川明, 小浜源郁, 他：口腔癌の領部リンハ 節転移に関する臨床病理学的検討一特に, 腫㻛 の浸潤様式との関速について。 日外誌 29 : 1555-1561 1983.

4）天笠光雄, 塩田重利, 他 : 舌癌の治療法別成績 一特に Stage I, II を中心に一 日癌治誌 20 : 758-764 1985.

5) 网本 学, 大関 悟, 他：嗹場の浸潤様式から みた舌癌の争後. 日口外誌 33：615-622 1987.

6) 山本悦秀, 小浜源郁, 他: 原発巣切除後, 局所 再発なく後発転移をきたした非進展舌癌の検討 一とくに腫㻛の浸潤様式との関連について。 日 口外誌 30:823-831 1984.

7）山本悦秀, 宮川明, 他：口腔粘膜癌の頸部》 ンパ節転移とその Bleomycin 感受性. 日口外 誌 30: 1824-1833 1984.

8) 奥田 稔, 吉井 功, 他: 舌瘦の転移につい て。 耳嶰 36: 907-914 1964.

9）立花忠夫：口腔領域扁平上皮癌の䫟部りン八節 転移に関与る臨床的ならびに病理組織学的研 究. 口病誌 52: 521-544 1985.

10）中村杜綱, 田代英雄, 他：口腔癌治瑔後の颙部 忶移発症例について。 日外誌 25：1034-1038 1979.

11）余藤利夫, 手島貞一, 他：口腔領域扁平上皮癌 の領域リンパ節転移に関する臨床統計的考察.

日口外誌 25: 778-783 1979.

12）新垣 普：口腔領城悪性腫場の領部 ンンパ節転 移に関する臨床病理学的研究. 日外誌 25 : 784-797 1979.

13）山下佐资：口院項域恵性腫㻛の頙部リンパ節転 
移に関する臨床病理学的研究. 鹿大医誌 18 : 674-698 1966.

14）堀 信一, 井上俊彦, 他: 舌瘐 TxNo 症例の 頸部リンパ節転移に関する検討。瘦の臨床 23: 507-510 1977.

15）作田正義，菅原利夫，他：頭頸部扁平上皮瘦の 転移形成に関する臨床的研究. 口科誌 30：1131981 .

16）工藤啓吾, 瀬川 清, 他：舌癌 31 症例の治療成 績に関する検討。日口外誌 32：211-216 1986.

17）三橋麗子：頭䫫部瘦の頸部転移についての臨床 的病理組織学的研究. 日耳鼻 71:621-639 1968.

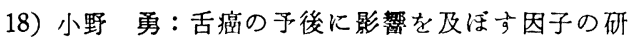
究. 日耳鲓 80：146-154 1977.

19）砂川 元, 山城正宏, 他：口腔領域患性腫場の 臨床病理学的研究 第 4 報 舌癌について。日 口科誌 35：873-880 1986.

20) Harmer, M.H.: TNM Classification of Malignant Tumors. 3 rd Ed, UICC, Geneva, 1978, p 23-26.

21）山本悦秀, 小浜源郁，他：び漫性浸潤型口腔扁 平上皮癌に関与る研究。日口外誌 28：147114791982.

22）山下微郎，水越孝典，他：局所放射線炤射線量 が抗腫瘍免疫と転移に及ぼす影響。癌の臨休
33: 1205-1210 1987.

23）松村智弘，菅原利夫，他：家鬼上靧洞に移植し た VX 2 carcinomaに対する局所 1 回照射の 肺転移に及ぼす影稫について。 日口外誌 1191221984 .

24）小川恭弘, 前田知穂, 他 : 瘦の放射線治療努果

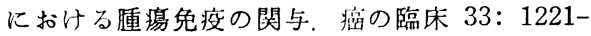
12281987.

25）梖殿玲子：放射線治療による免疫リンパ系綀胞 の障害を中心として。癌の臨床 33：1229-1237 1987.

26）山下幑郎, 早川邦雄, 他：cryosurgery による 癌転移の促進。癌と化学療法 5:110-114 1978.

27）宮田佳代子, 但守, 他: 頙頙部癌化学療法 に上る細胞性疫免能の変動. 瘦の臨休 33 : 1035-1038 1987.

28) Shingaki, S., Otake, K., et al: Regional Lymph node metastasis in carcinoma of the hamster tongue. Oral Surg 64: 190-196 1987.

29）平塚博義, 今村正克, 他: 舌癌組織内浸潤リン :球亚群の免疫組織学的解析とその臨床的意 義。札幌医誌 52：143-152 1983.

30）平塚博義, 小活源郁, 他: 舌癌 Stage I, II 症例の钼部後発転移に関寸る検討（抄），日口 外誌 32: 17181986. 